\title{
Genes and homogeneous trading groups: A comment on Janet Landa's target paper
}

\author{
Frank Salter
}

Published online: 16 November 2008

(C) The Author(s) 2008. This article is published with open access at Springerlink.com

In her target paper Janet Landa (2008) presents compelling evidence that cultural group strategies are a major factor underlying the development and continuity of ethnically homogeneous middleman trading groups (HMGs). HMG traders pass on the values and institutions underlying within-group trust and punishment of free-riders which in turn makes the group successful in risky markets. Landa finds that despite geographical separation the same HMG strategy has been adopted by different ethnic groups to guarantee contracts in societies with weak contract law. The finding of convergent cultural evolution is an important contribution to our knowledge of this subject.

I appreciate Landa's autobiographical approach. She recounts the development of her analysis beginning with her theory of ethnically homogeneous middleman groups as club-like trading institutions for contract enforcement in the early 1980s, followed by the incorporation of signaling theory, then HMGs as cultural transmission units in early 1990s, and finally her conceptualization of HMGs as adaptive units within the frame of multilevel-selection theory.

I find it significant that although Landa's analysis relies on gene-culture co-evolution theory it does not explore biological factors. Landa realizes that such factors must be included in a comprehensive theory (Footnote 5) but chooses to focus on cultural causes. In this comment I discuss some ways in which the analysis might be rounded out to include behavioral biological factors and suggest how these contribute to the success and continuity of HMGs. Landa's analysis provides some of the evidence needed to make this case.

Let us take a closer look at some key concepts, starting with 'adaptation'. The definition Landa quotes from Ghiselin entails survival and reproduction, which could

F. Salter $(\varangle)$

Research Group for Human Ethology, Max Planck Institute, Von-der-Tann-Str. 3,

82346 Andechs, Germany

e-mail: fssalter@aol.com 
be applied to genes. In neo-Darwinian theory genetic continuity and fitness are the criteria of adaptation. If HMGs are adaptive units, in the biological sense, they must at least preserve the genes of their constituent populations. In other words, to be adaptive they must transmit genes, whether or not they also transmit culture.

Indeed that appears to be the case with HMGs because all the examples described by Landa appear to be endogamous ethnic groups. An ethnic group is a named population whose members share a belief in common descent, have a shared history, a distinctive shared culture, a shared attachment to a homeland, and some degree of solidarity (Smith 1986, pp.22-30). The idea that shared belief in common descent is a core feature of ethnic identity goes back at least to Weber (1946/1922, p. 146). Improving gene assay data indicate that people are generally correct in their beliefs about shared ethnic origins (see review by Salter 2006/2003, Chap. 2). This is obviously true for endogamous minorities with historical memories of immigration from afar, which appears to be the case in all of Landa's examples.

The long range migration of ethnic middlemen means that their ethnic kinshipthe genetic similarity between random co-ethnics - is higher than it would be if they derived from the populations among whom they serve as middlemen. In such circumstances ethnic kinship can be as high as that found among extended families (Salter 2002). This means that the aggregate middleman ethnic group, numbering in the thousands, amounts to a large genetic family. Thus calling the differential survival and reproduction of HMGs group selection does not get to the point: it is actually a culturally assisted version of extended kin selection as set out by Hamilton (1971, 1975) and Harpending $(1979,2002)$. It is to be expected that solidarity is enhanced not only by religious and business institutions but by the often strong tie of ethnic identity, what van den Berghe (1981) calls ethnic nepotism, and the generally weak tie of gene-based similarity (Rushton 1989). Landa's emphasis of the 'immutable physical characteristics' that often distinguish ethnic/racial groups and which impede intercourse between them supports this interpretation.

Viewed in this light, HMGs are genetic as well as cultural group strategies in the sense that their distinguishing behaviors are caused by both genes and culture. The adaptiveness of these gene-culture manifolds increases both their genetic and cultural fitness.

The foregoing makes endogamy a critical variable for HMGs. All ethnic groups show some endogamy. Research into the affiliative effects of similarity show shared ethnicity to be among the strongest attractors of mates, friends and cooperators (McPherson et al. 2001; Thiessen and Gregg 1980). Long-lasting diaspora peoples, of which HMGs are examples, often institutionalize this universal tendency, I think as a means of reproducing the group boundary and its benefits. The process parallels the way spontaneous incest aversion is institutionalized in the form of incest prohibition (Westermarck 1936/1970, p. 258; Salter in press).

Already discussed is the way endogamy helps a HMG reproduce solidarity-trust and trustworthiness-down the generations by maintaining it as a descent group, a necessary condition of ethnicity. Institutions that work on and strengthen ethnic identity then maintain the collectivist advantages of reduced transaction costs and competitiveness against outsiders described in the target paper. 
HMG competitiveness is not due solely to club-like institutions operating in societies with underdeveloped contract law. Two locations of successful HMGs discussed by Landa, Amsterdam and New York, have had developed legal infrastructure for centuries. A cause of this success appears to be individual competitiveness. When traders possess human capital in the form of heritable traits that gives them an individual competitive edge endogamy will reproduce those traits. In addition to institutional synergies, members of HMGs also show strong work ethics and in most cases cited by Landa elevated cognitive ability compared to neighboring ethnic groups. Those traits are partly transmitted culturally in family and ethnic traditions. Landa documents the cultural roles performed by leading HMG traders. But there are also genetic causes of differences in IQ and conscientiousness, to name two characteristics bearing on academic and economic success (Bouchard 1997; Flynn 1991; Gottfredson 1997). At the end of the twentieth century average national IQ accounted for over $50 \%$ of the global variation in GDP (Lynn and Vanhanen 2002). The same trend is likely to apply to merchant groups because trading is cognitively demanding. Advantages in heritable human capital are maintained by endogamy by preventing regression to the general population mean (Salter 2008). Where no heritable advantage exists, endogamy is a precondition for such an advantage to evolve through individual or group selection.

HMG are indeed trait groups, as Landa argues from the perspective of multi-level selection theory. But they are trait groups not only because they reproduce culture but because as inbred populations they reproduce heritable behaviors.

Open Access This article is distributed under the terms of the Creative Commons Attribution Noncommercial License which permits any noncommercial use, distribution, and reproduction in any medium, provided the original author(s) and source are credited.

\section{References}

Bouchard, T. J. (1997). The genetics of personality. In K. Blum \& E. P. Noble (Eds.), Handbook of psychoneurogenetics (pp. 273-296). Boca Raton, FL: CRC Press.

Flynn, J. R. (1991). Asian Americans: Achievement beyond IQ. Hillsdale, NJ: Lawrence Erlbaum.

Gottfredson, L. S. (1997). Why g matters: The complexity of everyday life. Intelligence, 24(1), 79-132.

Hamilton, W. D. (1971). Selection of selfish and altruistic behavior in some extreme models. In J. F. Eisenberg \& W. S. Dillon (Eds.), Man and beast: Comparative social behavior (pp. 59-91). Washington, DC: Smithsonian Institute Press.

Hamilton, W. D. (1975). Innate social aptitudes of man: An approach from evolutionary genetics. In R. Fox (Ed.), Biosocial anthropology (pp. 133-155). London: Malaby Press.

Harpending, H. (1979). The population genetics of interactions. American Naturalist, 113, 622-630.

Harpending, H. (2002). Kinship and population subdivision. Population and Environment, 24(2), 141-147.

Landa, J. T. (2008). The bioeconomics of homogeneous middleman groups as adaptive units: Theory and empirical evidence viewed from a group selection framework. Journal of Bioeconomics Special Issue, 10(3). doi:10.1007/s10818-008-9043-8.

Lynn, R., \& Vanhanen, T. (2002). IQ and the wealth of nations. Westport, Conn.: Praeger.

McPherson, M., Lynn, S.-L., \& Cook, J. M. (2001). Birds of a feather: Homophily in social networks. In K. S. Cook \& J. Hagan (Eds.), Annual review of sociology (Vol. 27, pp. 415-444). Palo Alto, CA: Annual Review.

Rushton, J. P. (1989). Genetic similarity, human altruism, and group selection. Behavioral and Brain Sciences, 12, 503-559.

Salter, F. K. (2002). Estimating ethnic genetic interests: Is it adaptive to resist replacement migration? Population and Environment, 24(2), 111-140. 
Salter, F. K. (2006/2003). On genetic interests. Family, ethnicity, and humanity in an age of mass migration. New York: Transaction.

Salter, F. K. (2008). Westermarck's altruism: Charity releasers, moral emotions, and the welfare ethic. Politics and the Life Sciences (in press).

Smith, A. D. (1986). The ethnic origins of nations. Oxford: Basil Blackwell.

Thiessen, D., \& Gregg, B. (1980). Human assortative mating and genetic equilibrium: An evolutionary perspective. Ethology and Sociobiology, 1, 111-140.

van den Berghe, P. L. (1981). The ethnic phenomenon. New York: Elsevier.

Weber, M. (1946/1922). The nation. In H. H. Gerth \& C. W. Mills (Eds.), From Max Weber: Essays in sociology (pp. 171-179). New York: Oxford University Press.

Westermarck, E. (1936/1970). The future of marriage in Western civilization. Freeport, NY: Books for Libraries Press. 